\title{
STUDY OF COMMUNITY PARTICIPATION IN DEVELOPMENT OF NGADAS TRADITIONAL TOURISM VILLAGE IN PONCOKUSUMO DISTRICT, MALANG REGENCY
}

\author{
K P Linggarjati ${ }^{1}$, G Prayitno $^{2}$ and A D Wicaksono ${ }^{3}$ \\ Diterima: 14 September 2019 \\ Disetujui: 29 November 2019
}

\begin{abstract}
The development of a tourism village, from the beginning of the planning to the evaluation process must involve the local community as a form of community empowerment as the goal of tourism development that listed in Indonesian Tourism Master Plan year of 2011- 2025. It was revealed that the community tourism objects of the Malang Regency had not played an active role in the development of local attractions. In Ngadas Village itself, the community already knew their identity as a tourism village. However, the involvement and participation of the community in the development process has not been optimal. The level of participation was measured using eight stages of Arnstein's participation, divided into four stages of participation; planning phase, implementation phase, phase of use and monitoring phase. The results indicate that the level of community participation in the traditional Ngadas tourism village is still the third of eight stages in Arnstein's participation. Characteristics of the third ladder, named informing are where the community is passively involved by only being informed about the activities and the plans to be carried out, which have been decided before. Opinions and ideas from the community are not being a consideration that can influence the decisions.
\end{abstract}

Keywords: tourism village, level of participation and informing

\section{INTRODUCTION}

The development of tourism goes hand in hand with the growth of various concepts of tourism development approaches, such as the development of sustainable tourism, ecotourism, rural tourism, community tourism, in order to ensure that tourist activities can be conducted in rural tourist destinations. Empowerment efforts are needed to strengthen the community's role in tourism development so that the community can play a more active role and benefit from development activities aimed at improving well-being. Community participation is an important part of the tourism development process, based on the community. It is important to make decisions about tourism development and to determine the benefits that will be accepted as a consequence of tourism activities in rural areas (Raharjana, 2012)

In accordance with Government Regulation No. 50 year 2011 on the National Master Plan for Tourism Development for the period 2010-2025, the Community Empowerment through Tourism Policy aims at developing the potential, capacities and participation of communities. The strategy to increase the potential and capacity of local resources is through the development of tourist villages. Village tourism is a reflection of the original rural atmosphere that begins with everyday life, socio-economic, socio-cultural traditions,

\footnotetext{
${ }^{1}$ Departement of Urban and Regional Planning, Brawijaya University
} 
customs and traditions, building architecture and village spatial structures, as well as unique economic activities summarized in a rural area (Hadiwijoyo, 2012)

The Regency of Malang until 2017 has 15 tourist villages and 26 groups sensitized to tourism, called Pokdarwis. Two of the tourist villages are coastal tourist villages, namely the tourist village of Tambakrejo in Sendang Biru and the tourist village of Purwodadi in Tirtoyudo. Supporting Tourist Villages of Bromo Tengger Semeru National Park (TNBTS) are the Ngadas and Gubugklakah villages in Poncokusumo District.

The development of tourism goes hand in hand with the growth of various concepts of tourism development approaches such as sustainable tourism development, ecotourism, rural tourism, community based tourism in an effort to ensure tourism activities can be carried out in rural tourist destinations. Empowerment efforts are needed to enhance the role of the community in tourism development, so the community can play a more active role and get the benefits from the existence of development activities to improve welfare. Community participation is an important element in the process of developing tourism, with the community as a basis. It is important to make decisions in tourism development and the benefits that will be accepted as the implications of ongoing tourism activities in rural areas (Raharjana, 2012).

Based on Government Regulation Number 50 year of 2011 about the National Tourism Development Master Plan for 2010-2025, the direction of the policy of community empowerment through tourism is to develop potential, capacity and community participation. The strategy to increase the potential and capacity of local resources is through the development of tourism villages. Village tourism is a reflection of the original rural atmosphere starting from daily life, socio-economic, socio-cultural, customs and traditions, building architecture and village spatial structures with their own peculiarities as well as unique economic activities, summarized in a rural area (Hadiwijoyo, 2012; Prayitno \& Putri, 2019)

Malang Regency until 2017 has 15 tourism villages and 26 tourism conscious groups, called Pokdarwis. Two of the tourist villages are coastal tourism villages, namely Tambakrejo Tourism Village in Sendang Biru and Purwodadi Tourism Village in Tirtoyudo. While the supporting tourist villages of Bromo Tengger Semeru National Park (TNBTS) are Ngadas Village and Gubugklakah Village in Poncokusumo District.

Ngadas Village is one of the villages in Malang Regency which has been planned by the Tourism and Culture of Malang Regency as a traditional tourism village since 2014 and has been designated as one of the tourist destinations included in the Malang Regency tour package. The geographical position of Ngadas Village, flanked by Mount Bromo and Semeru become an advantage for Ngadas Village and also one of the villages residing in Tengger Tribe with traditions and cultures that still held firmly and still applied in various aspects of their life. Ngadas Village officially became the Ngadas Tourism Village based on the decree of the Departement of Tourism and Culture of Malang Regency Number 556/01/KEP/35.07.108/2017.

One important element in the development of sustainable tourism villages is the involvement or participation of local communities. Review of the Malang Regency MediumTerm Development Plan (RPJMD) for 2016-2021, states that communities around tourism objects have not played an active role in the development of local tourism objects. For this reason, it is necessary to conduct research to find out what level of community participation in the Ngadas Traditional Tourism Village uses the participation ladder by Sherry Arnstain (Arnstein, 1969).

Community participation in development planning is important because people are seen as better informed about their problems, interests and needs. Community participation is also community empowerment when the planning and implementation of development projects requires participation and the implementation of development requires the 
actualization of the community's willingness or ability to sacrifice and to contribute $[5,6]$. The distribution of power among community members themselves is an image of community participation (Arnstein, 1969)..

\section{Level of Participation}

Participation is seen as a bottom up development planning model that is suitable to be applied in Indonesia. In identifying community participation, a structure and grouping are needed on the level of participation in the community. According to Sherry Arnstein (Arnstein, 1969) in the Journal of the American Institute of Planners under the title "A Ladder of Citizen Participation", that there are 8 levels of participation based on the level of community power in influencing planning.

The bottom rungs of the ladder are (1) Manipulation and (2) Therapy. These two rungs describe levels of "non-participation" that have been contrived by some to substitute for genuine participation. Their real objective is not to enable people to participate in planning or conducting programs, but to enable powerholders to educate or cure the participants. Rungs 3 and 4 progress to levels of "tokenism" that allow the have nots to hear and to have a voice: (3) Informing and (4) Consultation. When they are proffered by power holders as the total extent of participation, citizens may indeed hear and be heard. But under these conditions they lack the power to insure that their views will be heeded by the powerful. When participation is restricted to these levels, there is no follow through, no muscle, hence no assurance of changing the status quo. Rung (5) Placation, is simply a higher level tokenism because the ground rules allow have-nots to advise, but retain for the power holders the continued right to decide. Further up the ladder are levels of citizen power with increasing degrees of decision-making clout. Citizens can enter into a (6) Partnership that enables them to negotiate and engage in trade-offs with traditional powerholders. At the topmost rungs, (7) Delegated Power and (8) Citizen Control, have-not citizens obtain the majority of decision-making seats, or full managerial power.

1. Manipulation

In the name of citizen participation, people are placed on rubberstamp advisory committees or advisory boards for the express purpose of "educating" them or engineering their support. Instead of genuine citizen participation, the bottom rung of the ladder signifies the distortion of participation into a public relations vehicle by power holders.

2. Therapy

In some respects group therapy, masked as citizen participation, should be on the lowest rung of the ladder because it is both dishonest and arrogant. Its administratorsmental health experts from social workers to psychiatrists-assume that powerlessness is synonymous with mental illness. On this assumption, under a masquerade of involving citizens in planning, the experts subject the citizens to clinical group therapy. What makes this form of "participation" so invidious is that citizens are engaged in extensive activity, but the focus of it is on curing them of their "pathology" rather than changing the racism and victimization that create their "pathologies."

3. Informing

Informing citizens of their rights, responsibilities, and options can be the most important first step toward legitimate citizen participation. However, too frequently the emphasis is placed on a one- way flow of information -from officials to citizens-with no channel provided for feedback and no power for negotiation. Under these conditions, particularly when information is provided at a late stage in planning, people have little opportunity to influence the program designed "for their benefit." The most frequent tools used for such one-way communication are the news media, pamphlets, posters, and responses to inquiries. 


\section{Consultation}

Inviting citizens' opinions, like informing them, can be a legitimate step toward their full participation. But if consulting them is not combined with other modes of participation, this rung of the ladder is still a sham since it offers no assurance that citizen concerns and ideas will be taken into account. The most frequent methods used for consulting people are attitude surveys, neighbourhood meetings, and public hearings.

\section{Placation}

It is at this level that citizens begin to have some degree of influence though tokenism is still apparent. They allow citizens to advise or plan ad infinitum but retain for power holders the right to judge the legitimacy or feasibility of the advice. The degree to which citizens are actually placated, of course, depends largely on two factors: the quality of technical assistance they have in articulating their priorities; and the extent to which the community has been organized to press for those priorities.

6. Partnership

At this rung of the ladder, power is in fact redistributed through negotiation between citizens and power holders. They agree to share planning and decision-making responsibilities through such structures as joint policy boards, planning committees and mechanisms for resolving impasses. After the ground rules have been established through some form of give-and-take, they are not subject to unilateral change.

\section{Delegated Power}

Negotiations between citizens and public officials can also result in citizens achieving dominant decision making authority over a particular plan or program. At this level, the ladder has been scaled to the point where citizens hold the significant cards to assure accountability of the program to them. To resolve differences, power holders need to start the bargaining process rather than respond to pressure from the other end.

8. Citizen Control

Demands for community controlled schools, black control, and neighbourhood control are on the increase. Though no one in the nation has absolute control, it is very important that the rhetoric not be confused with intent. People are simply demanding that degree of power (or control) which guarantees that participants or residents can govern a program or an institution, be in full charge of policy and managerial aspects, and be able to negotiate the conditions under which "outsiders" may change them.

\section{Scale of Participation}

The level of participation needs to be measured by appropriate indicators to assess community participation. The measurement can be done by measuring the level of individual participation or individual involvement in communal activities, which can be measured by the scale proposed by Chapin [7], namely: (1) Membership in the organization, (2) Attendance at meetings, (3) Donations, (5) Membership in management, and (5) Position of members in management.

\section{Stage of Participation}

Cohen and Uphoff (1977) cited by Soetomo (2008) divide community participation in development into 4 stages, namely:

1. Planning Stage

According to C. Erison in Slamet [8] participation in the planning stage is being active in making suggestions. Participation in making a decision is very necessary because it involves the fate of the community itself.
2. Implementation Stage 
Participation in the implementation is in the form of willingness to contribute in the form of energy, participation in the form of money, participation in the form of property, participation in ideas, expertise and skills. In addition, community activity in the implementation of development and responsibility for the success of development is also participation in the implementation phase.

3. Utilization Stage

Manifested by the involvement of someone at the stage of utilizing a program after the program has been completed. Community participation at this level is in the form of energy and money to operate and maintain programs that have been implemented. The stage of enjoying the results can be used as an indicator of the success of community participation in the planning and implementation stages of the program.

4. Monitoring and Evaluation Stage

Manifested by the participation of the community in assessing and monitoring development activities and their results. Community participation at this stage is feedback that can provide input to improve the implementation of the next program.

\section{METHODS}

Research variables are elements of a group of research objects or something that concern in a study that will be studied. Arikunto [9] explains that the variable is an object or also the subject under study or which is the focal point of a study. Based on the theory and results of previous studies, the variables that will be discussed and examined in the study can be seen in Table 1.

Table 1. Research Variables

\begin{tabular}{lll}
\hline \multicolumn{1}{c}{ Variables } & \multicolumn{1}{c}{ Sub Variables } & \multicolumn{1}{c}{ Indicators } \\
\hline Level of & Level of participation in planning stage & Frequency of attendance \\
Participation & & Membership in institutions \\
& Level of participation in implementation & Frequency of attendance \\
& stage & Involvement in physical activities \\
& Level of participation in utilization & Engagement utilizes results \\
& stage & Donations \\
& Level of participation in monitoring and & Participation in monitoring and evaluating \\
evaluation stage & Membership in institutions \\
\hline
\end{tabular}

Source: $[10,12,13,15$

Scoring and weighting analyzes were carried out to measure the level of participation using Arnstein's theory [4]. To determine the level of community participation at each stage, measured by the sum of the scores of the indicators. The total value level of the participation variable can be calculated by the score, multiplied by the weight of each of the participation steps of Arnstein. After the interval calculation is done, to get the class division is using below.

$$
\text { Interval }=\frac{\text { maximum score }- \text { minimum score }}{\text { classifications }}
$$

Table 2. Level of Participation Score Interval

\begin{tabular}{llc}
\hline Number of Ladder & Level of Participation & Score Interval \\
\hline 8 & Citizen Control & $1589-1815$ \\
7 & Delegated Power & $1362-1588$ \\
6 & Partnership & $1135-1361$ \\
5 & Placation & $908-1134$
\end{tabular}




\begin{tabular}{llc}
\hline Number of Ladder & Level of Participation & Score Interval \\
\hline 4 & Consultation & $681-907$ \\
3 & Informing & $454-680$ \\
2 & Therapy & $227-453$ \\
1 & Manipulation & $0-226$ \\
\hline
\end{tabular}

\section{RESULTS AND DISCUSSION}

Ngadas Village is one of 36 Tengger Tribe villages in four districts, namely Malang Regency, Probolinggo Regency, Pasuruan Regency, and Lumajang Regency. Geographically, Ngadas Village is in the coordinates of $7.5890^{\circ}$ South Latitude and $112.5455^{\circ}$ East Longitude [14]. Ngadas village is surrounded by forest areas in mountainous areas with an area of 13,751.6 ha. Located at an altitude of 2157 masl with an average daily temperature reaching $4-20^{\circ} \mathrm{C}$.

\section{Planning Stage}

The level of community participation in the planning stage using indicators of membership in village institutions and the frequency of attendance at meetings.

Table 3. Respondent's Participation Level of Their Membership In the Institution

\begin{tabular}{|c|c|c|c|c|}
\hline Scoring Scale & Respondent & $\%$ & Weight & $\mathrm{R} \times \mathrm{W}$ \\
\hline Not a member of the institution & 85 & 37,6 & 0 & 0 \\
\hline Become a member of the institution forcefully & 0 & $0,0 \%$ & 1 & 0 \\
\hline Become a member of the institution to get information & 41 & $18,1 \%$ & 2 & 82 \\
\hline $\begin{array}{l}\text { Become a member of the institution to get information } \\
\text { and not }\end{array}$ & 25 & $11,1 \%$ & 3 & 75 \\
\hline $\begin{array}{l}\text { Become a member of the institution and have the } \\
\text { opportunity to }\end{array}$ & 43 & $19,0 \%$ & 4 & 172 \\
\hline Become a member of an institution, actively expressing & 13 & $5,8 \%$ & 5 & 65 \\
\hline Become a member of the institution and get a division of & 13 & $5,8 \%$ & 6 & 78 \\
\hline $\begin{array}{l}\text { Become a member of the institution and have the } \\
\text { authority to }\end{array}$ & 3 & $1,3 \%$ & 7 & 21 \\
\hline $\begin{array}{l}\text { Become a member of the institution and be able to } \\
\text { control all }\end{array}$ & 2 & $0,9 \%$ & 8 & 16 \\
\hline Total & 226 & $100 \%$ & & 509 \\
\hline
\end{tabular}

From the indicators of membership of existing institutions in the Ngadas Traditional Tourism Village, the level of community participation resulted in a score of 509 which was classified as the level of informing participation.

The frequency of attendance indicators at meetings resulted in a score of 731 which was classified as the participation consultation level. The average score of participation at the planning stage of the development of Ngadas Traditional Tourism Village is 620. It can be concluded that participation at the planning stage is at the third level of participation ladder, namely informing.

In the planning stage, the community is involved in meetings only as participants where the plans or topics to be discussed has been arranged in advance regarding tourism development plans and activities to be held at the previous meeting, which involved only the village officials, community leaders, members of village tourism institutions and the head of RT/RW. The community has the opportunity to ask questions, give opinions and suggestions. However, there is no negotiating power from the community or there is no guarantee that what is conveyed by the public can influence decisions that have been planned in advance. 


\section{Implementation Stage}

The level of participation at the implementation stage using indicators of attendance frequency indicators at tourism training and involvement in physical activities.

Table 4 Respondent's Participation Level in Frequency of Attendance at Tourism Training

\begin{tabular}{lcccc}
\hline \multicolumn{1}{c}{ Scoring Scale } & Respondent & $\%$ & Weight & R x W \\
\hline Not invited & 89 & $39 \%$ & 0 & 0 \\
Invited but not Attend & 12 & $5 \%$ & 1 & 11 \\
Attend just to fulfil the invitation & 36 & $16 \%$ & 2 & 72 \\
Attend to obtain information, without conveying ideas & 35 & $16 \%$ & 3 & 105 \\
$\begin{array}{l}\text { Attend to get information and submit ideas, but your } \\
\text { ideas are not considered }\end{array}$ & 20 & $9 \%$ & 4 & 80 \\
$\begin{array}{l}\text { Attend and provide ideas and few are considered or } \\
\text { made as }\end{array}$ & 22 & $10 \%$ & 5 & 110 \\
decisions & & & & \\
Attend and get a division of responsibility & 10 & $5 \%$ & 6 & 60 \\
Attend and have the power to carry out ideas & 2 & $1 \%$ & 7 & 14 \\
Attend and have full power to control the entire & 0 & $0 \%$ & 8 & 0 \\
training process & & & & \\
Total & 226 & $100 \%$ & & 452 \\
\hline
\end{tabular}

The attendance indicators in the tourism training activities held at the Ngadas Traditional Tourism Village resulted in a score of 452 which was classified as the level of therapy participation.

The indicators of involvement in physical activities resulted in a score of 470 which was classified as the level of informing participation. The average level of participation at the stage of implementation of the development of Ngadas Traditional Tourism Village is 461. It can be concluded that participation at the implementation stage is at the third level of participation ladder, namely informing.

Only members of village tourism institutions and tourism actors registered under the auspices of the institution and members of the PKK were involved when there was tourism training. In addition, the community will participate in physical activities for tourism development such as making tourist parking lots, spot photos and planting Adas plants if they get an invitation to participate. All activities have been determined by the village tourism institution and only a few are conveyed if the activity affects to the community and the lack of meetings and discussions to respond to each other.

\section{Utilization Stage}

The level of community participation in the utilization stage using indicators of willingness to pay donations and involvement utilizes the results of tourism training.

Table 5. Respondent's Participation Levels in Willingness to Pay Donations

\begin{tabular}{|c|c|c|c|c|}
\hline Scoring Scale & Respondent & $\%$ & Weight & $\mathrm{R} \times \mathrm{W}$ \\
\hline Don't want to pay donations village institutions & 2 & $0,9 \%$ & 0 & 0 \\
\hline $\begin{array}{l}\text { Paying the least because they are forced and not } \\
\text { paying village institutions }\end{array}$ & 17 & $7,5 \%$ & 1 & 17 \\
\hline $\begin{array}{l}\text { Pay donations and not paying attention to its } \\
\text { utilization reports/criticisms of tourist village } \\
\text { institutions }\end{array}$ & 62 & $27,4 \%$ & 2 & 124 \\
\hline $\begin{array}{l}\text { Pay donations without getting the opportunity to } \\
\text { submit the reports/criticisms but not necessarily be } \\
\text { responded }\end{array}$ & 57 & $25,2 \%$ & 3 & 171 \\
\hline Pay donations and get the opportunity to submit the & 45 & $19,9 \%$ & 4 & 180 \\
\hline
\end{tabular}
proposed further consideration 


\begin{tabular}{lcccc}
\hline \multicolumn{1}{c}{ Scoring Scale } & Respondent & $\%$ & Weight & R x W \\
\hline $\begin{array}{l}\text { Pay donations and give a little proposal for use in the } \\
\text { field }\end{array}$ & 41 & $18,1 \%$ & 5 & 205 \\
$\begin{array}{l}\text { Pay donations and get an equal distribution of } \\
\text { responsibilities in }\end{array}$ & 7 & $3,1 \%$ & 6 & 42 \\
$\begin{array}{l}\text { Pay donations and have the authority to implement } \\
\text { proposed responsibilities }\end{array}$ & 6 & $2,7 \%$ & 7 & 42 \\
$\begin{array}{l}\text { Paying and being able to control the entire decision } \\
\text { making decisions }\end{array}$ & 0 & $0,0 \%$ & 8 & 0 \\
Total & 226 & $100 \%$ & & 781 \\
\hline
\end{tabular}

The indicator of willingness to pay donations or contributions to the development activities of the Ngadas Traditional Tourism Village it resulted in a score of 781 which was classified as the level of informing participation.

The indicator of participation in continuing the results of the training resulted in a score of 388 which was classified as the level of therapy participation. The average level of participation at the stage of utilization of the development of the Ngadas Traditional Tourism Village is 585. It can be concluded that participation at the implementation stage is at the third level of participation ladder, namely informing.

The results of the trainings that have been given not yet specifically seen. For example, training on making souvenirs such as processed food and drinks typical of Ngadas, which was attended by PKK members. Based on the results of interviews with the community and the Ngadas Village, there is no community that focuses on processing, selling and storing the stock of souvenirs on a regular basis. The souvenirs are only processed when there are special orders from guests or materials for typical village product exhibition activities.

In the existing condition, there is no funding contribution or pay donations from the community. But, it becomes a consideration if there is an urgent need and the development activity is not supported by the availability funds from the Regional Budget, Malang Regency's Departement of Tourism and Culture as well as other sources and proposals.

\section{Monitoring and Evaluation Stage}

The level of community participation in the monitoring and evaluation stage using indicators of membership in village institutions in monitoring and providing criticism of the work of the Dewi Adas Tourism Village Institute and participation in monitoring and evaluating.

The indicator of membership in institutions in the Traditional Tourism Village resulted in a score of 413 which was classified as the level of therapy participation.

In the indicators of participation in monitoring and evaluating tourism activities in the village as well as the work of the Dewi Adas Tourism Village Institute, it resulted in a score of 591 which was classified as an informing level of participation. The average score of participation at the monitoring and evaluation stage in the development of Ngadas Traditional Tourism Village is 502 . It can be concluded that participation at the monitoring and evaluation stage is at the third level of participation ladder, namely informing.

In its existing conditions, the community can only be involved in preventive monitoring activities to prevent negative actions on all tourism activities that can disrupt the security of Ngadas Village and not care about what the Dewi Adas Tourism Village Institute has done. In addition, evaluation activities are also only carried out internally between village officials, village tourism institutions, collaborative institutions and the Departement of Tourism and Culture of Malang Regency. 
Table 6. Respondents' Participation Level in their Membership in Village Institutions

\begin{tabular}{|c|c|c|c|c|}
\hline Scoring Scale & Respondent & $\%$ & Weight & $\mathrm{R} \times \mathrm{W}$ \\
\hline Not a member of an institution in the village & 85 & $37,6 \%$ & 0 & 0 \\
\hline $\begin{array}{l}\text { Become a member who is passive and not care about } \\
\text { tourism village institutions }\end{array}$ & 29 & $12,8 \%$ & 1 & 29 \\
\hline $\begin{array}{l}\text { Become a member only to be informed and } \\
\text { indifferent to tourist village institutions }\end{array}$ & 32 & $14,2 \%$ & 2 & 64 \\
\hline $\begin{array}{l}\text { Become a member to get information without } \\
\text { submitting reports/criticisms of tourist village } \\
\text { institutions }\end{array}$ & 27 & $11,9 \%$ & 3 & 81 \\
\hline $\begin{array}{l}\text { Become a member and have the opportunity to } \\
\text { submit reports/criticisms but not necessarily be } \\
\text { responded to }\end{array}$ & 32 & $14,2 \%$ & 4 & 128 \\
\hline $\begin{array}{l}\text { Become a member and submit reports / criticisms } \\
\text { and make further consideration }\end{array}$ & 17 & $7,5 \%$ & 5 & 85 \\
\hline $\begin{array}{l}\text { Become a member and get a division of supervisory } \\
\text { responsibilities }\end{array}$ & 2 & $0,9 \%$ & 6 & 12 \\
\hline $\begin{array}{l}\text { Become a member and have the authority to } \\
\text { supervise and make decisions }\end{array}$ & 2 & $0,9 \%$ & 7 & 14 \\
\hline $\begin{array}{l}\text { Become a member and be able to control all } \\
\text { decisions }\end{array}$ & 0 & $0,0 \%$ & $\varepsilon$ & 0 \\
\hline Total & 226 & $100 \%$ & & 413 \\
\hline
\end{tabular}

\section{All Stages of Participation in The Development of Ngadas Traditional Tourism Village}

The level of community participation in the development of Ngadas Traditional Tourism Village can be known by summing all scores at each stage of development and averaged (Table 7).

Table 7. Respondent's Participation Level in All Stage of Participation

\begin{tabular}{llll}
\hline Number & Stage of Participation & Score & Level of Participation \\
\hline 1. & Planning Stage & 620 & Informing \\
2. & Implementation Stage & 461 & Informing \\
3. & Utilization Stage & 612 & Informing \\
4. & Monitoring and Evaluation Stage & 502 & Informing \\
Total & & 2195 & \\
\hline
\end{tabular}

So the level of community participation in the development of Ngadas Traditional Tourism Village is included in the level of informing participation because it has a score of 544.25. People can participate by being welcome to argue and will be heard, but there is no negotiating power from the community or there is no guarantee that what is conveyed by the public can influence the decisions.

\section{CONCLUSIONS}

The level of community participation in the Ngadas Traditional Tourism Village at all stages of development resulted in an average score of 544.25. The score falls into the category of informing participation, where the level is in the third level of the Arstein participation ladder. People can participate and are welcome to hear and will be heard but there is no negotiating power from the community or there is no guarantee that the community can influence decisions.

It can be concluded that community participation in the development of Ngadas Indigenous Tourism Village is still categorized as tokenism. Tokenism is participation which is merely an award or justification for the community to agree. Getting information and 
opportunities to argue for improvement of decisions but often will not be accommodated or considered.

\section{REFERENCES}

Raharjana, D. T. 2012. Membangun Pariwisata Bersama Rakyat: Kajian Partisipasi Lokal Dalam Membangun Desa Wisata di Dieng Plateau. Kawistara Vol. 2, 225-328.

Hadiwijoyo, S. S. 2012. Perencanaan Pariwisata Perdesaan Berbasis Masyarakat (Sebuah Pendekatan Konsep). Yogyakarta: Graha Ilmu.

Prayitno G., Sari N, Putri I.K.. 2019. Social Capital In Poverty Alleviation Through Pro- Poor Tourism Concept in Slum Area (Case Study: Kelurahan Jodipan, Malang City). Internatinal Journal of GEOMATE. Vol.16, Issue 55, March 2019

Arnstein, R. 1969. A Ladder of Citizen Participation. Journal of the American Institute of Planners, 216-224.

Rahardjo, A. (2006). Membangun Desa Partisipatif. Yogyakarta: Graha Ilmu.

Prayitno, G., and Subagiyo A. 2018. Membangun Desa. UB Press

Slamet, Y. (1994). Pembangunan Masyarakat Berwawasan Partisipasi. Surakarta: Sebelas Maret University Press.

Soetomo. 2008. Strategi-Strategi Pembangunan Masyarakat. Yogyakarta: Pustaka Pelajar.

Arikunto, S. 1995. Manajemen Penelitian. Jakarta: PT. Rineka Cipta.

Suciati. 2006. Partisipasi Masyarakat Dalam Penyusunan Rencana Umum Tata Ruang Kota Pati. Semarang: Program Pasca Sarjana Magister Teknik Pembangunan Wilayah Dan Kota Universitas Diponegoro.

Chusnah, Ummul. 2008. Evaluasi Partisipasi Masyarakat dalam Pelaksanaaan Program Peningkatan Kualitas Sarana Prasarana Pendidikan di SMAN 1 Surakarta. Program Pasca Sarjana Magister Teknik Pembangunan Wilayah Dan Kota Universitas Diponegoro.

Cohen, J. and Uphoff, N. 1980. Rural Development Participation Concept and Measure for Project Design Implementation and Evaluation. New York: Cornell University.

Mustikawati. 2016. Partisipasi Masyarakat dalam Pembangunan Infrastruktur Desa di Desa Rapak Lambur Kecamatan Tenggarong Kabupaten Kutai Kartanegara. Jurnal Ilmu Administrasi Negara. Vol. 4, No. 2. Hlm. 2739-2752.

Badan Pusat Statistik Kabupaten Malang. 2017. Kecamatan Poncokusumo Dalam Angka. Malang: Badan Pusat Statistik Kabupaten Malang.

Krejcie, R.V., \& Morgan, D.W. 1970. Determining Sample Size for Research Activities. Educational and Psychological Measurement, 30, 607-610. 